\title{
Brexit and UK International Development Policy
}

\author{
Simon Lightfoot ${ }^{1}$, Emma Mawdsley ${ }^{2}$ and Balázs Szent-Iványi ${ }^{3}$ \\ ${ }^{1}$ University of Leeds, POLIS \\ 2 University of Cambridge, Department of Geography \\ ${ }^{3}$ Aston University, Aston Centre for Europe
}

\begin{abstract}
In this paper we explore the implications of Brexit for the UK and the EU's development policies and strategic directions, focussing on the former. While it is likely that the operational process of disentangling the UK from the various development institutions of the EU will be relatively straight-forward, the choices that lie ahead about whether and how to cooperate thereafter are more complex. Aid and development policy touches on a wide range of interests - security, trade, climate change, migration, gender rights and so on. We argue that Brexit will accelerate existing trends within UK development policy, notably towards the growing priority of private sector-led economic growth strategies and blended finance tools. There are strong signals that UK aid will be cut, as successive Secretaries of State appear unable to persuade a substantial section of the public and media that UK aid and development policy serves UK interests in a variety of ways.
\end{abstract}

Keywords: UK, EU, international development, foreign aid

\section{Introduction}

In the recent debates about the impact of Brexit on different policy areas, ${ }^{1}$ one underexamined is that of international development assistance. This is surprising, as Britain is

\footnotetext{
${ }^{1}$ See Political Quarterly vol. 87, no. 2 (2016). It is also noticeable that Brexit has been discussed by the House of Commons Foreign Affairs Committee but to date there has been no formal report from the International Development Committee.
} 
generally seen as a highly influential actor in the international development system, a view that has been reinforced in recent years with the increase in foreign aid spending to $0.7 \%$ of gross national income (GNI) in 2014, and the ring fencing of the development aid budget from budgetary austerity measures. ${ }^{2}$ Moreover, international development policy intersects with a very wide range of issues, including security, trade, immigration, climate change and diplomatic platforms. The implications of Brexit for the UK's aid and development institutions and agendas therefore touch on many strategic concerns.

'Development' is a long-standing EU foreign policy instrument, regarded in recent years as a European success in which the UK has played a significant role. ${ }^{3}$ Indeed, there is evidence that the UK has been able to leverage its membership in the EU to achieve considerable influence. Brexit will have impacts both on the EU's and the UK's development assistance policy, with implications for financing, policy priorities, and operational functioning. This article concentrates mainly on the issues the UK now faces, and also focuses on what needs to be settled during the Brexit negotiations. It argues that Brexit will reinforce an already obvious realignment in the UK's international development policy towards more explicit and expanded focus on UK economic and geopolitical interests. The UK is not alone in this, and similar trends can be found in other EU member states. The implications for the EU'S development strategy following the UK's exit are therefore contextualised within a broader era of turbulence for development partners. The actual process of disentangling UK development policy from the EU will be comparatively easy, although the UK will have to make key decisions on how much it will want to work together with the EU in the future.

\section{Context}

\footnotetext{
2 J. Fisher, 'Does it work? Work for whom? Britain and Political Conditionality since the Cold War', World Development, vol. 75, no. November, 2015, pp. 13-25; A. Manji, 'The International Development (Official Development Assistance Target) Act 2015: legislative spending targets, poverty alleviation and aid scrutiny', Modern Law Review, vol. 79, no. 4, 201, pp. 655-77.

${ }^{3}$ LSE Commission on the Future of Britain in Europe, Britain as a Global actor after Brexit. Report of the hearing held on 1st March, 2016. Available online at: http://www.Ise.ac.uk/europeanlnstitute/LSECommission/Hearing-7---Britain-as-a-Global-actor-after-BREXIT-REPORT.pdf.
} 
EU development policy is set down in Articles 208-211 of the Treaty on the Functioning of the European Union (TFEU). The policy is a shared parallel competence, meaning that member states retain their own development policies, but the European Commission (EC) also manages a common foreign aid budget, in effect acting as a $29^{\text {th }}$ donor. This common foreign aid budget is made up of a part of the EU budget (under heading 4, 'The EU as a global player'), to which all member states have a legal obligation to contribute. In addition, the UK contributes to the European Development Fund (EDF), an extra-budgetary fund focused specifically on financing development assistance for the African, Caribbean and Pacific (ACP) countries. The total amount of aid spent by the EC, from both the budget and the EDF, was $f 8.8 \mathrm{bn}$ in 2015 , making it one of the world's largest donors. The UK has been a significant contributor to the EU's development budget, funding more than $15 \%$ (f1.3bn) of it in $2015,{ }^{4}$ and making the EU the UK's largest multilateral partner.

The EC is, however, not just an additional donor. It also has the role of coordinating the activities of the member states through the proposition of rules and norms for member state behaviour, which are then approved by the Council. In the past decade, the EU has promoted rules on increasing aid, making aid more effective, and enhancing cooperation between member states, among others. These rules however are soft: while member states acting in the Council have agreed to adopt these rules, they have no legal obligation to do so, and the EC has very few enforcement tools to push non-compliant members towards adoption/adaptation. The literature generally agrees that, at worst, member states cherry pick these rules, adopt the ones which fit their interests, and at best pay lip service to the rest. $^{5}$

There has been no academic research to date on exactly how much of this soft law the UK has actually adopted, but many aspects of UK aid policy seem to be aligned with it well. These include meeting the $0.7 \%$ aid/GNI target, prioritising aid to poorer countries and implementing measures to improve the effectiveness and transparency of aid. Indeed, the Department for International Development's (DFID) 2016 Multilateral Development Review

\footnotetext{
${ }^{4}$ All data on aid from OECD.Stat. Available online at: http://stats.oecd.org/Index.aspx?datasetcode=TABLE1.

${ }^{5}$ See, for example, J. Orbie and M. Carbone, 'The Europeanisation of development policy', European Politics and Society, vol. 17, no. 1, 2015, pp. 1-11.
} 
rated the match between EU and UK development policy objectives as 'very good' (something which was not the case for most of the other multilaterals reviewed). ${ }^{6}$

The perceived advantages of working through the EU's development mechanisms are that the EU's global reach is greater than that of any of the Member States acting individually and that the EU can act as a multiplier for member state influence. Given that there was seen to be a close alignment between UK and EU development objectives, this meant that UK influence could be magnified. The reverse side is that EU aid is naturally a compromise which may mean that the UK's position might not always be at the forefront. In addition, despite improvements, EU aid is widely seen as overly complex and the division of labour between the EC's Directorates-General and the European External Action Service (EEAS) is still yet to become fully clear. In the 2011 Multilateral Aid Review, the development part of the EU budget (excluding humanitarian aid) was assessed as 'adequate value for money'. ${ }^{7}$

Finally, the UK context is similar to that of many other advanced aid donor countries, with the UK's development assistance strategy undergoing significant changes in recent years. Four particularly important trends are evident: the focus on fragile states; the growing emphasis on economic growth (rather than poverty reduction per se), with particular prominence for private sector-led development; the routing of a higher share of aid through ministries other than DFID; and the exit or transition from many former recipient countries. Security concerns have long been one dimension of the UK's development policy aims, and this has certainly been the case under the Conservative government. In 2010, DFID was enrolled as the junior partner in a new National Security Council together with the Ministry of Defence (MoD) and the Foreign and Commonwealth Office (FCO). Indeed, in 2015 the International Development Committee solicited views on whether or not DFID should be reabsorbed into the FCO, something that was not pursued, but it is notable that it was on the table at all. The wider context prompting these strategic changes includes a more complex global geography of poverty and wealth (exemplified by the case of India, for example); the opportunities and contestation provided by the 'rising powers' as international

6 DFID, Raising the standard: the Multilateral Development Review 2016, p. 16. Available online at: https://www.gov.uk/government/uploads/system/uploads/attachment_data/file/573884/Multilateral-

Development-Review-Dec2016.pdf.

${ }^{7}$ House of Commons Library, Brexit: impact across policy areas, Briefing Paper Number 07213, 26 August 2016 
development actors (for example, China's growing footprint in Africa); and the political and economic consequences of the global financial crisis, domestically and abroad. Brexit is therefore one of many issues re-shaping UK foreign aid, but clearly a very important one. In the following section, we examine the immediate impacts of the referendum outcome, followed by an exploration of some of the longer term possible implications.

\section{Immediate impacts of the referendum}

The results of the referendum on 23 June 2016 had an immediate impact on UK aid, with the fall in the value of the pound leading to considerable pressure on overseas budgets in other currencies. More fundamentally, the decision emboldened the critics of UK aid, and especially the commitment to $0.7 \%$ aid/GNI spending. Various opinion polls have shown that a majority of people favour cutting the UK's aid budget, with this majority being made up of a similar demographic to those of voted Brexit. ${ }^{8}$ The Daily Mail, one of the main Brexitbacking newspapers and the one with the longest reach of the daily papers, ${ }^{9}$ has been involved in a prolonged campaign against foreign aid.

We see a similar position of aid scepticism and anti-Europe sentiment within many parts of the Conservative Party. ${ }^{10}$ Ever since the election of the Conservative-led coalition in 2010, successive Secretaries of State for International Development have assiduously tried to persuade critics that UK aid supports British interests, even as it does 'good' in the world. Andrew Mitchell, development secretary between 2010 and 2012, for example, made explicit some of the ways in which aid serves the UK economy, is a tool of soft power, and helps underpin national security in a variety of ways. Thus this is not a new narrative, but following the Brexit debates and decision, the Conservative government led by Theresa May has provided ever stronger signals about the need to justify and interpret development aid in new ways. The appointment of Priti Patel as the Secretary of State for DFID, exemplifies

\footnotetext{
${ }^{8}$ G. Davies, S. Lightfoot and R. Jones, 'UK foreign aid: what do the British public think aid should be for?' Available online at: http://blogs.Ise.ac.uk/politicsandpolicy/uk-foreign-aid-what-do-the-british-public-thinkaid-should-be-for/.

${ }^{9}$ A. Menon and J.-P. Salter, 'Brexit: initial reflections', International Affairs, vol. 92, 2016, pp. 1297-1318.

${ }^{10}$ T. Bale and P. Webb, 'Not as Bad as We Feared or Even Worse Than We Imagined? Assessing and Explaining Conservative Party Members' Views on Coalition', Political Studies, vol. 64, no. 1, 2016, pp. 123-142.
} 
this. Patel was one of the leading figures in the Brexit campaign, and has a well-known record of hostility to UK aid. While currently constrained by the legislation requiring a commitment of $0.7 \% \mathrm{GNI}$ to aid, she represents and voices a hard-headed insistence on the primacy of British interests, on not 'wasting' aid, and on the centrality of economic growth. As noted above, these are not new directions or narratives, but Patel gives them a powerful figurehead and force. The 2016 Autumn Statement mentioned the possibility of amending the 2006 International Development Act, and it is entirely possible that as well as redirecting and re-purposing aid to better and more openly serving UK interests (while still claiming to be doing good), that it will be significantly cut. It is possible, however, that exposure to DFID and its work around the world (see below) might adjust Patel's knowledge and understanding of the ways in which aid serves UK interests, and what the UK would lose out if it was substantially reduced. Whether or not aid allocation is reduced though, she is accelerating and deepening the directions taken by her predecessors to deploy aid to more openly serve UK geoeconomic interests.

\section{Longer term implications of Brexit for UK aid}

\section{Impact on UK brand/soft power}

The UK - primarily through the auspices of DFID - wields very considerable soft power in the international development realm. The Conservative government is open about this, the 2015 UK Aid policy for example states:

UK leadership in [tackling poverty] will cement our global moral leadership, and make a strong contribution to the UK's soft power and our ability to project our influence across the globe. ${ }^{11}$

DFID is widely admired by its peers in the industry as one of the world's leading development agencies. ${ }^{12}$ It is large, relatively well funded, and just as importantly, since its establishment in 1997, DFID has consistently sought to provide normative leadership at the

11 DFID, UK aid: tackling global challenges in the national interest, 2015, p. 18. Available online at: https://www.gov.uk/government/uploads/system/uploads/attachment data/file/478834/ODA strategy final web 0905.pdf.

12 OECD-DAC, Peer Review UK, 2014. 
international level. International development is an arena within which the UK has been able to project itself, shaping debates and promoting UK interests and agendas. Historically, where this has mattered is within the 'traditional' multilateral institutions, such as the EU, UN agencies, the OECD DAC and the Bretton Woods institutions. But now there are a suite of newer and potentially highly strategic international forums and institutions opening up, with 'rising power' membership a key threat/incentive to join and assert influence. For example, the UK manoeuvred hard for then Secretary of State Justine Greening to be one of the three Co-Chairs of the Global Partnership for Effective Development Cooperation (GPEDC), established in 2011. In this the UK was successful, and in the GPEDC's formative phase, the UK represented the 'established' donors with the two other co-chairs coming from Nigeria and Indonesia. In 2012 the Secretary General of the UN established a HighLevel Panel of Eminent Persons on the Post-2015 Development Agenda, appointing David Cameron as one of the three Co-Chairs, together with President Ellen Johnson Sirleaf of Liberia and President Susilo Bambang Yudhoyono of Indonesia. These positions and others like them enable UK leaders, diplomats and civil servants to project direct and indirect influence over international norms, debates and policy statements in emerging forums.

However, the UK government must contend with a national-international disconnect. There is good evidence that a majority of the UK general public are not strongly aware of what DIFD is, or what it does. ${ }^{13}$ The soft power rationale is more evident to government, policy and some business circles, but has limited popular purchase. This is despite clear attempts by successive Secretaries of State to make the connections explicit, such as Priti Patel's recent statement that: 'British soft power is exactly where DFID, and our aid and other relationships around the world, come together to deliver in our national interest and deliver for Britain when it comes to free trade agreements but also life post-Brexit. ${ }^{14}$

Although the legal spending commitment remains, there are growing signs that the law will be reviewed. Chancellor Philip Hammond said that all areas of spending would be reexamined and a spokeswoman for the Prime Minister made clear that overseas aid would

\footnotetext{
${ }^{13}$ A. Darnton, The Public, DFID and Support for Development, A Rapid Review. London: Andrew Darnton for DFID, 2009.

${ }^{14}$ The Guardian, 'Priti Patel warns aid organisations must provide value for money or face cuts', 25 October 2016.
} 
be part of the review, saying there were no commitments 'beyond' the current Parliament. ${ }^{15}$ This is not a direct result of Brexit but as shown above, part of the reorientation within the Conservative party to reflect more closely the views of the Brexiters. If aid is cut, then the UK can expect to lose some of its 'brand' image and soft power influence.

But complicating this picture is the context - declining aid from other Western aid donor partners meaning that relative losses might not look so large; the declining power of the Western donors as key actors in shaping the norms of international development; and the move away from traditional concepts of aid towards emerging forms of blended finance. Here the UK is likely to remain competitive, and indeed, an ideational leader. For example, Justine Greening made a point of delivering keynote speeches from the London Stock Exchange, and invoking the UK's prominence in financial services as a tool for development, although whether the UK remains such a high profile donor without the multiplier effect of the $\mathrm{EU}$ is difficult to predict.

\section{Implications for UK development policy directions}

As noted above, the UK is already moving strongly towards narratives, policies and institutions that elevate economic growth as the engine of development, rather than a focus on poverty reduction per se. While poverty reduction programmes and goals certainly remain important, much of the new energy and investment of the Conservative aid strategy has been in stimulating trade and private sector-led development. Supporters of Brexit insist that Britain will be able to grow its trade with non-EU partners, and it is critical for the May government that it does so. There is a clear narrative that Brexit will accelerate the trend to utilise aid to secure trade deals. ${ }^{16}$ Again, Brexit is likely to strengthen existing policy directions rather than upset them. Patel's first tour as Secretary of State was to India, a visit that was dominated by discussions of cooperation in trade, investment and financial services. There is a clearly a risk here - while 'development and trade policy have always

\footnotetext{
${ }^{15}$ Independent, 'Theresa May set to cut $0.7 \%$ foreign aid spending commitment, Downing Street signals', 13 December 2016.

${ }^{16}$ E. Mawdsley, 'DFID, the Private Sector and the Re-centring of an Economic Growth Agenda in International Development', Global Society, vol. 29, 2015, pp.339-358.
} 
been "closely coupled, but (this) can create problems," because a country's "things to sell are not necessarily the things (its beneficiaries) need."'17

There is an option to increase the volume of aid devoted to business investment. This would fit with the proposal from DFID to increase the support the government can give to CDC, the UK development finance institution from $£ 1.5 \mathrm{bn}$ to $£ 6 \mathrm{bn}$. Any spending via CDC must conform to the (current) UK law that international development spending must have the goal of poverty reduction at its core. Given the increased media and political attention on how and where UK aid is spent, CDC spending would be carefully scrutinised but the direction of travel away from (recent) 'traditional' aid is clear.

The UK has been sharply reducing the number of its development partners in the past years, while seeking to 'transition' its development relationships with strategic partners. This process may end with Brexit, and in fact there may be reasons in some cases for it to reverse. Many states of strategic interest to the UK are supported through EU development policy and receive little or no UK bilateral aid. It may be important for UK soft power to extend focus to these countries to compensate for the influence lost via the EU. There is also a scenario whereby without the UK's influence, the EU's aid budget could be reorientated towards the Southern and Eastern neighbourhoods at the expense of the Commonwealth countries in the ACP. This might force the UK to increase funding to Commonwealth countries to compensate. ${ }^{18}$

\section{Disentangling from EU development policy}

The actual process of disentangling the UK's development assistance policy from the EU will be relatively simple, at least compared to other policy areas. As mentioned, most of the legislation in the field is in the form of soft law, and it is likely that the UK conforms only to those aspects that fit its interests anyway. Most of the issues thus involve the UK's financial contributions to the EU's development budget, and making a decision on the degree to

\footnotetext{
${ }^{17}$ CNBC, 'Aid for trade: The UK's foreign support budget could be used to boost post-Brexit business', 27 October 2016.

${ }^{18}$ S. Price, 'Brexit, Development Aid, and the Commonwealth', The Round Table, vol. 105, no. 5, 2016, pp. 499507.
} 
which the UK would like to remain involved in funding various aspects of EU development policy, and benefitting from some less visible, but very tangible benefits.

One of these issues relates to the EU's relations with the ACP countries. The EU has created formal institutional arrangements for regulating political, economic and development relations with these countries, currently governed by the Cotonou Agreement. The EU has also created the EDF to support development activities in the ACP countries. As mentioned, the fund is independent from the EU's budget, and is replenished by member states every 5 to 7 years.

Essentially, the ACP group is comprised on the former colonies of member states, and institutionalised relationships with them go back to the early 1960s. The special status of this grouping in EU development policy can be seen as somewhat anachronistic, but has it has survived all attempts at reform. It was the accession of the UK in 1973 and the need to extend the EU-ACP relationship to the UK's former colonies which prompted a significant revamp in 1975, leading to the Lomé Conventions. These were superseded by the Cotonou Agreement in 2000, which is set to expire in 2020. The current, $11^{\text {th }}$ EDF also runs between 2014 and 2020, and the UK has a legal obligation to contribute close to $€ 4.5$ billion, or $14.7 \%$ of the fund's total during this period. ${ }^{19}$ With Brexit currently projected for 2019, the UK might have to contribute to EDF for an additional year. Also, a significant portion of EDF funds is usually not spend in the given programming period and carried over to the next. Both of these mean that there is a strong possibility that development resources provided by the UK will be allocated without any say from the UK, albeit for a short time only.

Clearly, the UK has a strong stake in how political relations between the Europe and the ACP countries evolve, given how many ACP countries are members of the Commonwealth. Negotiations on the successor of the Cotonou Agreement will start in 2018, but the Commission has already laid out its vision on the renewal of the partnership in late 2016, and it emphasizes involving 'like minded' countries in the new agreement. ${ }^{20}$ This provides a possibility for the UK to remain engaged with EU-ACP relations after Brexit, but it is likely

19 See the relevant EU legislation, available online at https://ec.europa.eu/europeaid/sites/devco/files/internal-agreement-11edf-2013-2020 en.pdf.

${ }^{20}$ Joint Communication to the European Parliament and the Council. A renewed partnership with the countries of Africa, the Caribbean and the Pacific. JOIN (2016) 52 final, p. 4. 
that to get a seat at this table, it will need to commit to contributing to the EDF in the future.

There are other aspects of EU development policy the UK might opt to remain involved in. Given that DFID's focus on fragile states mirrors that of the EU, the post-Brexit UK will need to consider benefits of working with the EU on police or military missions. Other options, such as bilateral or UN missions, do exist, but the government will need to decide whether the costs, especially in terms of creating new administrative structures outweigh the benefits. Both Switzerland and Norway plan to contribute to the EU External Investment Plan and the Emergency Trust Fund for Africa, both of which are essentially EU efforts to use development assistance to reduce migration. The fact that non-EU countries, realising the common European interest, have opted to take part in these, imply that there is case for the UK to make a similar decision. The EU has so far set up relatively few trust funds, but it is likely to make greater use of these instruments in the future, and the UK might need to decide on a case-by-case basis whether to contribute to these or not.

A further issue relates to EU aid coordination. As mentioned, the EC does not simply act as a $29^{\text {th }}$ donor, but since the Treaty of Maastricht in 1992, has been steadily carving itself a role as the coordinator of member state aid activities. The lack of coordination between aid donors has long been recognised as being a major impediment to effective aid. ${ }^{21}$ The aid coordinating activities of the EC, especially on the policy level, have however been hampered by the lack of legally binding tools and the general unwillingness of member states. None the less, the EU has made progress on coordination in terms of implementation: EU Delegation Offices have emerged as the main drivers of field-level coordination between European donors present in the given country by organising regular meetings between EC and member state development diplomats. ${ }^{22}$ This has greatly improved the flow of information between donors, although there is variation depending on the specific developing country context. In a recent communication on the future of EU development policy, the EC has emphasized how the global development agenda, centred

\footnotetext{
${ }^{21}$ S. Delputte and J. Orbie, 'The EU and Donor Coordination on the Ground: Perspectives from Tanzania and Zambia', European Journal of Development Research, vol. 26, no. 5, 2014, pp. 676-691.

22 M. Carbone, 'Between EU actorness and aid effectiveness: The logics of EU aid to Sub-Saharan Africa', International Relations, vol. 27, no. 3, 2013, pp. 341-355.
} 
around the UN's Sustainable Development Goals, can only be achieved with the support of well coordinated aid, and it intends to become a more important actor in the field. ${ }^{23}$ The UK, while also emphasizing the importance of coordination among donors of aid, has been lukewarm at best about the EC's attempts to coordinate the aid policies of member states, but is heavily engaged in field level coordination. Leaving the EU will cut the UK off from the EC's coordination activities. Policy level coordination also takes place in other forums, such as the OECD's Development Assistance Committee (DAC), so the UK could bolster its presence there. Leaving field level EU coordination initiatives however poses a big challenge, as it will significantly decrease the amount of information British development diplomats have access to about the activities of other countries. Britain therefore might opt to continue taking part in these, provided the EU member states are willing to have it.

\section{Conclusions}

The limited attention towards international development policy following the Brexit referendum is partly a reflection of the policy area falling between the stools of 'hard' foreign policy and domestic politics. It is also safe to assume that the UK's bilateral development policy does not look the way it does because of the EU, and indeed policy papers published by DFID rarely contain references to the EU. This also implies that leaving the EU is unlikely to change the major contours of UK development policy, as the EU has had little influence on it in the first place. Brexit will rather reinforce already existing changes driven by the Conservative government towards a greater emphasis on economic growth and British interests.

After Brexit, Britain will remain part of other key forums which set the global development agenda, such as the OECD DAC, where it can make efforts to increase its influence. Also, being outside of the EU does not mean that a constructive dialogue with the integration on development policy matters will not be possible, and there are areas where such engagement would be in the UK's interest. The EU will also miss the UK's contribution to its

\footnotetext{
${ }^{23}$ Communication from the Commission to the European Parliament, the Council, the European Economic and Social Committee and the Committee of the Regions. Proposal for a new European Consensus on Development Our World, our Dignity, our Future. COM(2016) 740 final.
} 
global influence and especially its aid budget with one analysis highlighting that the EU would miss DFID more than DFID would miss the EU'. ${ }^{24}$

However, the fact that the UK will have until 2019 at the earliest to revisit this policy means that it needs to start thinking about these issues now - not least because this policy area has the potential to make a major difference to people's lives. It is also vital to undertake more research in this area as the UK's relationship with the developing world has many facets and in the Brexit negotiations there is a risk that this area will get overlooked. Yet in aid, trade, climate change and taxation there are important policy decisions to be made. The interconnection between foreign policy and international development policy will become increasingly important post-Brexit, especially for UK's soft power. Brexit involves disentangling the UK from over 40 years of EU membership with the associated policy decisions around immigration and trade policy to environmental and gender policy. It also needs to be ensured that the developing world has a voice in this discussion, as the decision taken on the $23^{\text {rd }}$ of June has massive consequences beyond the borders of this island.

24 LSE Commission on the Future of Britain in Europe, Britain as a Global actor after Brexit. Report of the hearing held on 1st March, 2016. Available online at: http://www.Ise.ac.uk/europeanlnstitute/LSECommission/Hearing-7---Britain-as-a-Global-actor-after-BREXIT-REPORT.pdf. 